\title{
Identification of Soybean Genes Whose Expression is Affected by the Ensifer fredii HH103 Effector Protein NopP
}

\author{
Jinhui Wang ${ }^{1,+}{ }^{\dagger}$,jieqi Wang ${ }^{1, \dagger}{ }^{+}$, Chunyan Liu ${ }^{1}$, Chao Ma ${ }^{1}$, Changyu Li ${ }^{1,+}$, Yongqian Zhang ${ }^{1}$, \\ Zhaoming Qi ${ }^{1, *}$, Rongsheng Zhu ${ }^{1}$, Yan Shi ${ }^{1}$, Jianan Zou ${ }^{1}$, Qingying Li $^{1}$, Jingyi Zhu ${ }^{1}$, \\ Yingnan Wen ${ }^{1}$, Zhijun Sun ${ }^{1}$, Hanxi Liu ${ }^{1}$, Hongwei Jiang ${ }^{1}$, Zhengong Yin ${ }^{1,2}$, Zhenbang Hu ${ }^{1}$, \\ Qingshan Chen ${ }^{1, *}$, Xiaoxia $\mathrm{Wu}^{1, *}$ and Dawei Xin ${ }^{1, *}$ \\ 1 Key Laboratory of Soybean Biology of Chinese Ministry of Education, Key Laboratory of Soybean Biology \\ and Breeding/Genetics of Chinese Agriculture Ministry, College of Science, Northeast Agricultural \\ University, Harbin 150030, China; jinhuiwang113@126.com (Jin.W.); jieqi0719@126.com (Jie.W.); \\ cyliucn@126.com (Chu.L.); mcneau@163.com (C.M.); m15754506980@163.com (Cha.L.); \\ qian13039802199@163.com (Y.Z.); rshzhu@126.com (R.Z.); llowkeyy@126.com (Y.S.); \\ nachtschatten1994@163.com (Jia.Z.); 15545127190@163.com (Q.L.); jingyizhu1107@126.com (Jin.Z.); \\ wyn8952@126.com (Y.W.); sunzhijunwork@163.com (Z.S.); liuhanxi396525797@163.com (H.L.); \\ j3994102@126.com (H.J.); yinzhengong@163.com (Z.Y.); hzb_net@126.com (Z.H.) \\ 2 Heilongjiang Academy of Agricultural Sciences, Harbin 150030, China \\ * Correspondence: qizhaoming1860@126.com (Z.Q.); qshchen@126.com (Q.C.); xxwu2012@126.com (X.W.); \\ xdawei@163.com (D.X.); Tel.: +86-0451-5519-1945 (Q.C.); +86-0451-5519-1945 (X.W.); \\ +86-0451-5519-1945 (D.X.) \\ + These authors contributed equally to this work.
}

Received: 14 September 2018; Accepted: 30 October 2018; Published: 2 November 2018

\begin{abstract}
In some legume-rhizobium symbioses, host specificity is influenced by rhizobial nodulation outer proteins (Nops). However, the genes encoding host proteins that interact with Nops remain

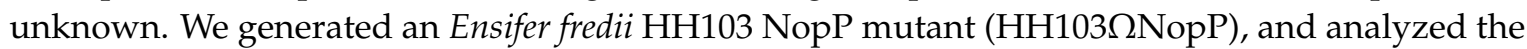
nodule number $(\mathrm{NN})$ and nodule dry weight (NDW) of 10 soybean germplasms inoculated with the wild-type E. fredii HH103 or the mutant strain. An analysis of recombinant inbred lines (RILs) revealed the quantitative trait loci (QTLs) associated with NopP interactions. A soybean genomic region containing two overlapping QTLs was analyzed in greater detail. A transcriptome analysis and qRT-PCR assay were used to identify candidate genes encoding proteins that interact with NopP. In some germplasms, NopP positively and negatively affected the NN and NDW, while NopP had different effects on NN and NDW in other germplasms. The QTL region in chromosome 12 was further analyzed. The expression patterns of candidate genes Glyma.12g031200 and Glyma.12g073000 were determined by qRT-PCR, and were confirmed to be influenced by NopP.
\end{abstract}

Keywords: soybean; NopP; symbiosis; QTL

\section{Introduction}

Soybean (Glycine max (L.) Merr.), which is an important protein source for humans and animals [1], establishes a symbiotic relationship with rhizobia in different soil environments [2]. Rhizobia can enter soybean roots by infecting root hairs, after which they can stimulate the curling of root hair tips and the formation of an infection chamber containing entrapped bacteria. Rhizobia enters root hairs through infection threads that develop within epidermal root hair cells and migrate to the inner root tissues. The infection thread, containing dividing bacteria, elongates and forms branches to reach 
root cortical cells where a nodule primordium is formed [3]. When rhizobia (Bradyrhizobium and Ensifer species) symbiotically colonize soybean roots, the plants can fix atmospheric nitrogen in a process known as biological nitrogen fixation (BNF) [4], which is an efficient and environmentally friendly source of nitrogen. Ensifer fredii $\mathrm{HH} 103$ strain was first isolated as a fast-growing Rhizobium japonicum from a soybean nodule in China $[5,6]$. Previous studies revealed that $E$. fredii strains grow much faster than Bradyrhizobium species, and can nodulate at least 79 different genera of legumes (i.e., a very broad host range) [7,8]. Specifically, E. fredii HH103 can nodulate many legumes, including soybean, which is considered its natural host plant [9]. Since genomic and transcriptomic studies of Ensifer fredii HH103 are available, this strain is a good candidate for investigating specific gene functions [8,10-13]. Also, the capacities of Ensifer fredii HH103 to grow faster than bradyrhizobia and nodulate soybean, make this strain valuable for understanding molecular mechanisms acting in the soybean-rhizobia interaction.

The nodule organogenesis process requires different signal exchanges between the symbiotic partners [14]. Understanding these signal exchange mechanisms is necessary to apply BNF in agriculture. For example, Nod factors are essential for the initiation of symbiosis with legumes. Meanwhile, flavonoids from host plants interact with rhizobial NodD proteins to activate the production of Nod factors. Legumes perceive Nod factors via Nod-factor receptors, such as MtNFH1, to regulate nodulation. Additionally, the Nod-factor signaling pathway induces the expression of the symbiosis-related genes required for bacterial infections and nodule formation [15]. Rhizobia have many microbe-associated molecular patterns (MAMPs), including flagellin, lipopolysaccharides, exopolysaccharides, and $\beta$-glucans, but limited searches indicated that these rhizobial MAMPs appear to lack MAMP activities [16]. One study concluded that a peptidoglycan-modifying enzyme in rhizobia is required for bacteroid differentiation in Aeschynomene species, implying that peptidoglycans influence nodule functions [17]. In the legume-rhizobium interaction, effector- or MAMP-triggered plant immunity mediated by host receptors is important for regulating the rhizobial host range [18,19]. Rhizobia can inject many effector proteins into host cells via type III, type IV, or type VI secretion systems. The roles of these effectors are presumably similar to those of effectors from plant pathogens, which promote the infection process $[20,21]$. The mechanisms underlying signal exchanges will need to be characterized to enhance the application of BNF as an agricultural practice. In some legume-rhizobium symbioses, the type III secretion system (T3SS) is important for nodulation and host-range determination [8,22-24]. In rhizobia, the proteins secreted by the T3SS are collectively known as nodulation outer proteins (Nops); at least 11 secreted proteins, NopA, NopB, NopC, NopD, NopJ, NopL, NopM, NopI, NopP, NopT and NopX have been identified in Ensifer fredii [25-39], all of them being present in strain $\mathrm{HH} 103$ [9].

The NopP type III-secreted effector protein was first identified in $R$. fredii (E. fredii) strain NGR234 [27]. The E. fredii USDA257 NopP is secreted into the interior of cowpea root cells, suggesting it may be a real effector [40]. The NopP identified in E. fredii HH103 is similar to that of NGR234, and can influence GmPR1 expression during the HH103 infection of soybean [41]. Earlier studies determined that GmPR1 is a member of a protein family that includes enzymes (e.g., chitinase and $\beta$-1,3-glucanase) that can directly attack pathogen structures, thereby acting as antimicrobial compounds [42-44]. Similar to NopL, NopP is also phosphorylated by an unknown kinase in plants, but its specific function is unknown [30]. In plants, NopP may interact with anti-pathogenic signals, like NopL, because NopP is also phosphorylated by its substrate [41]. Additionally, Rj2 encodes a typical R protein belonging to the Toll-interleukin receptor/NBS/LRR class. Previous studies confirmed that Rj2 restricts the nodulation involving specific rhizobial strains, such as Bradyrhizobium diazoefficiens USDA122 [45,46]. The results of the current study indicate that Rj2-producing soybean plants may restrict nodulation via effector-triggered immunity (ETI). The inactivation of the T3SS restores the ability of $B$. diazoefficiens USDA122 to nodulate the Rj2-producing soybean cultivar Hardee [47]. A recent study revealed that NopP interacts with Rj2 to mediate the incompatibility between rhizobia and soybean. However, the NopP effector and the molecular mechanism underlying this genotype-specific incompatibility 
with the Rj2-producing soybean remain unknown. Many researches have proved that NopP played an important role during rhizobia infecting plant, but beside Rj2, no proteins that directly interacts with NopP were found in the legume host [48].

Quantitative trait locus (QTL) mapping is an ideal method for mapping genomic regions associated with ecologically and evolutionarily important traits. However, there are relatively few reports describing the mapping of soybean genes responsible for nodule traits [49]. Research since the 1950s aimed at detecting genomic loci related to nodulation [50] has led to the identification of several loci, including $r j 1, r j 2, r j 3, r j 4, r j 5, r j 6, r j 7$, and $r j 8$ [51-55]. Moreover, rj2 and $r j 4$ were recently cloned $[56,57]$. The $r j 2$ gene encodes a determinant of symbiotic specificity that is dependent on the T3SS in USDA257 [58]. Furthermore, Rj4 reportedly regulates the incompatibility and compatibility between soybean and rhizobia, and type III effectors of Bradyrhizobium elkanii may be associated with the incompatibility with soybean carrying the Rj4 gene [59]. Identification of host genes interacting with specific rhizobial effectors would facilitate the understanding of the molecular mechanisms involved in the host regulation of symbiosis.

In this study, we identified QTLs encoding proteins that interact with NopP in a recombinant inbred line (RIL) derived from a cross between soybean germplasms Dongnong594 and Charleston, which have contrasting nodule phenotypes. Additionally, soybean genes whose expression is affected by NopP were identified.

\section{Results}

\subsection{NopP Effects on Soybean Germplasm}

In this study, we used 10 soybean germplasms derived from different ecoregions to elucidate the role of NopP in the symbiotic relationships between rhizobia and soybean. In most soybean germplasms, the nodule number (NN) and nodule dry weight (NDW) were significantly different depending on whether the germplasms were inoculated with the NopP mutant or the wild-type strain. Additionally, NopP had a negative effect on the NNs of germplasms, except for the landraces Suinong14, Qingdou and Dongnong594 (Figure 1). However, Qingdou inoculated with HH103 has

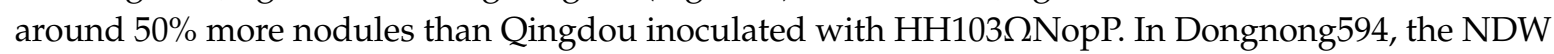
increased in response to the infection by the E. fredii HH103 $\Omega$ NopP strain. Thus, NopP positively and negatively affected the symbiotic relationships between $\mathrm{HH} 103$ and soybean, with the differences in the symbiotic phenotypes among germplasms influenced by their genetic backgrounds.

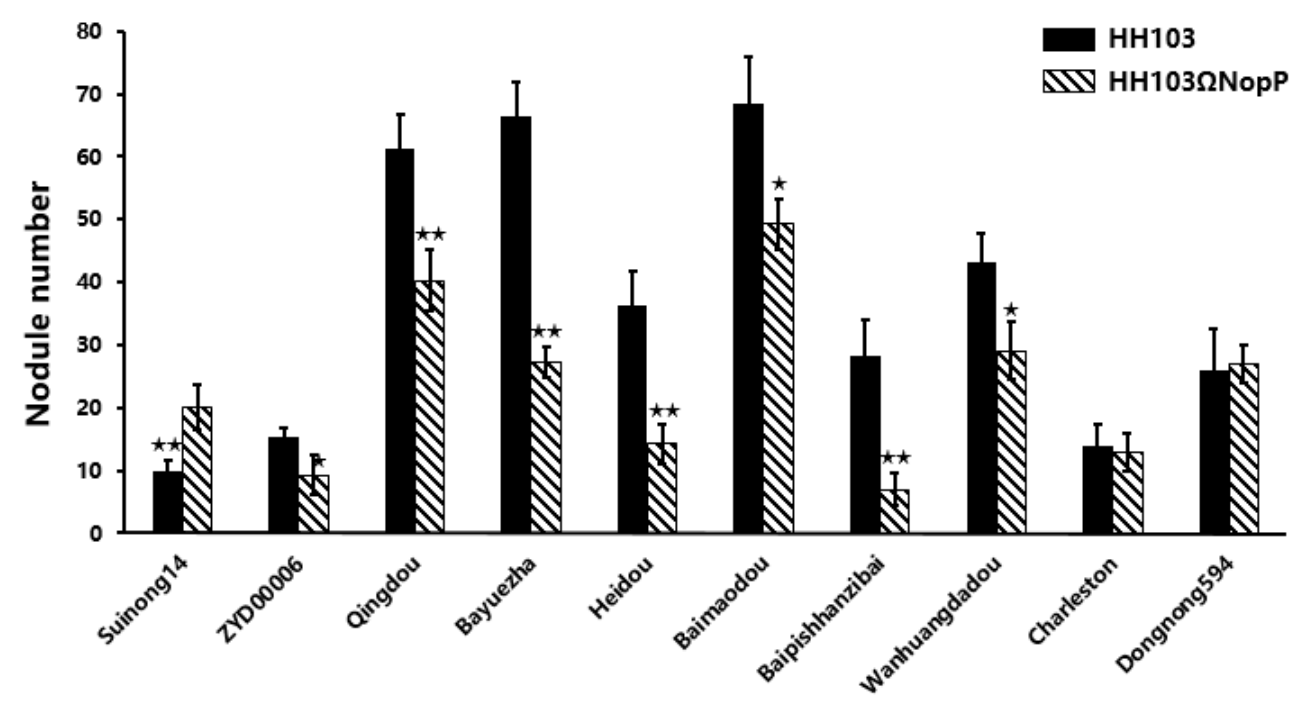

Figure 1. Cont. 


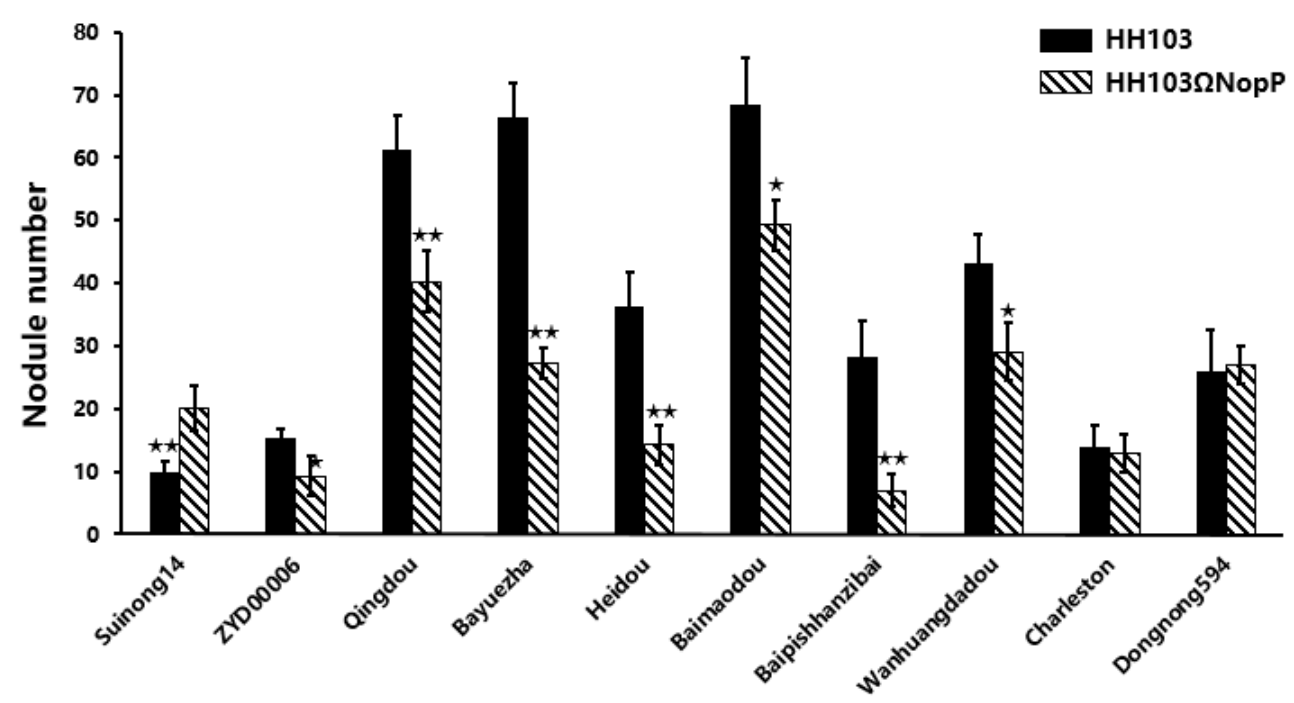

Figure 1. Nodule phenotype of soybean germplasm after inoculation with Ensifer fredii $\mathrm{HH} 103$ and

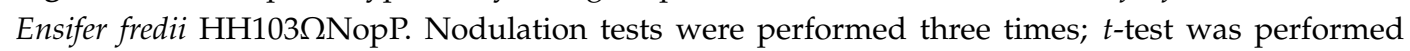
comparing the NopP mutant to the wild type strain; when significant $(0.01 \leq p \leq 0.05)$, an asterisk is shown, ** indicate $p \leq 0.01$. Ecoregions origin of germplasms: Suinong14 (Heilongjiang), ZYD00006 (Heilongjiang), Qingdou (Shanxi), Bayuezha (Zhejiang), Heidou (Zhejiang), Baimaodou (Zhejiang), Baipishanzibai (Shanxi), Wanhuangdadou (Anhui), Charleston (America), Dongnong594 (Heilongjiang).

\subsection{Phenotypic Analysis}

The NN and NDW values were significantly different between Charleston and Dongnong594 (Table 1). The NN and NDW data for the RIL population varied, with no significant trend observed for NN. A comparison of the NDWs for the RILs suggested that the NopP mutant increased the NDW in most RILs.

Table 1. Parental and population statistics for nodule traits in the soybean 'Charleston' $\times$ 'Dongnong594' population.

\begin{tabular}{ccccccc}
\hline & \multicolumn{4}{c}{ RILs $(\boldsymbol{n}=\mathbf{1 5 0})$} & \multicolumn{2}{c}{ Parents (Average) } \\
\cline { 2 - 7 } & Traits & Average & $\begin{array}{c}\text { Standard } \\
\text { Deviation }\end{array}$ & $\begin{array}{c}\text { Coefficient } \\
\text { of Variation }\end{array}$ & Charleston & Dongnong594 \\
\hline \multirow{2}{*}{ HH103 Rif ${ }^{\mathrm{R}}$} & Nodule number & 23.9 & 15.1 & 76.38 & $14.0 \pm 3.5^{* *}$ & $26.0 \pm 6.6$ \\
\cline { 2 - 7 } & $\begin{array}{c}\text { Nodule } \\
\text { dry-weight }(\mathrm{mg})\end{array}$ & $18.4^{*}$ & 17.2 & 93.25 & $13.0 \pm 2.6^{* *}$ & $22.5 \pm 1.8$ \\
\hline $\begin{array}{c}\text { HH103 } \\
\text { Rif }{ }^{\mathrm{R}} \Omega \text { NopP }\end{array}$ & \begin{tabular}{c} 
Nodule number \\
\cline { 2 - 7 }
\end{tabular} & $11.5^{* *}$ & 13.822 & 58.07 & $13.0 \pm 3.0^{* *}$ & $27.0 \pm 3.0$ \\
\hline & Nodule & 29.4 & 0.0236 & 80.34 & $10.0 \pm 2.6^{* *}$ & $41.5 \pm 5.6$ \\
\hline
\end{tabular}

${ }^{*}$ indicate $p \leq 0.05,{ }^{* *}$ indicate $p \leq 0.01$.

\subsection{Mapping of Conditional QTL for Nodulation-Related Traits}

Three and four conditional QTLs were identified for NN and NDW, respectively, after inoculations with the wild-type E. fredii HH103 and NopP mutant strains (Table 2 and Figure 2). The conditional QTLs for NN were located on Gm03, Gm14, and Gm17, while the conditional QTLs for NDW were located on Gm03 (1), Gm12 (2), and Gm16 (1).

No overlapping QTLs were detected for NN and NDW, although two QTLs located on Gm12 were close to each other, with one at $51.8 \mathrm{cM}$ and the other at $55.5 \mathrm{cM}$. These two QTLs had not been previously identified, but as previous studies had mapped interaction in some adjacent QTLs 
with nodulation or pathogen-resistance $[49,50]$, we were interested in whether the QTLs in our study could interact with NopP. As previously mentioned, NopP may be phosphorylated by a host kinase, and it can also influence legume immunity (e.g., ETI). Predicted soybean protein-coding DNA sequences from QTL regions and adjacent regions were retrieved from the Phytozome database (www.phytozome.net/soybean) and then annotated by using them as queries in BLASTX searches of the Glycine max Wm82 proteome. On the basis of the main protein domains, we selected 17 genes related to disease-resistance, signal transduction, and nodule formation on Gm12 for further analyses (Table 3).

Table 2. Chromosomal localization of conditional QTLs for nodule-related traits.

\begin{tabular}{lllllll}
\hline Trait & LG/QTL & Chrom. & Position (cM) & LOD $^{\mathbf{a}}$ & $\mathbf{R}^{\mathbf{2}} \mathbf{( \% )}$ & ADD $^{\mathbf{c}}$ \\
\hline \multirow{3}{*}{ Nodule number } & QN/NN01 & 03 & 55.5 & 3.8 & 8.21 & -2.46 \\
& QB2/NN02 & 14 & 74.0 & 4.6 & 9.04 & -2.95 \\
& QD2/NN03 & 17 & 133.2 & 5.0 & 8.19 & 2.61 \\
\hline \multirow{5}{*}{ Nodule dry weight } & QN/NDW01 & 03 & 74.0 & 5.0 & 2.54 & -0.001 \\
& QH/NDW02 & 12 & 51.8 & 4.0 & 9.78 & 0.005 \\
& QH/NDW03 & 12 & 55.5 & 5.4 & 3.75 & 0.002 \\
& QJ/NDW04 & 16 & 88.8 & 4.5 & 5.26 & -0.002 \\
\hline
\end{tabular}

a LOD: $\log$ of odds. ${ }^{\mathrm{b}} \mathrm{R}^{2}$ (\%): the contribution rate of the QTL; ${ }^{\mathrm{c}} \mathrm{ADD}$ : the additive effects contributed by the QTL; LG: Linkage group; QN: QTL on LG N, QB2: QTL on LG B2, QD2: QTL on LG D2, QH: QTL on LG H, QJ: QTL on LG J.

Table 3. Relevant information of candidate genes belonging to the two overlapping conditional QTLs for NDW.

\begin{tabular}{lll}
\hline No. & Gene & Function \\
\hline 1 & Glyma.12G028300 & Cell elongation protein/DWARF1/diminuto (DIM) \\
2 & Glyma.12G030000 & Leucine-rich repeat protein kinase family protein \\
3 & Glyma.12G030300 & Disease resistance-responsive (dirigent-like protein) family protein \\
4 & Glyma.12G030900 & Like auxin resistant 2 \\
5 & Glyma.12G031000 & Pathogenesis-related thaumatin superfamily protein \\
6 & Glyma.12G031200 & Pathogenesis-related thaumatin superfamily protein \\
7 & Glyma.12G032400 & Calcium-dependent lipid-binding (CaLB domain) family protein \\
8 & Glyma.12G036700 & NAD(P)-linked oxidoreductase superfamily protein \\
9 & Glyma.12G036900 & NAD(P)-binding rossmann-fold superfamily protein \\
10 & Glyma.12G040000 & Leucine-rich receptor-like protein kinase family protein \\
11 & Glyma.12G043600 & Protein kinase superfamily protein \\
12 & Glyma.12G052400 & Protein kinase family protein \\
13 & Glyma.12G055500 & Leucine-rich repeat (LRR) family protein \\
14 & Glyma.12G055600 & Leucine-rich repeat (LRR) family protein \\
15 & Glyma.12G073000 & Mitogen-activated protein kinase 3 \\
16 & Glyma.12G076200 & Auxin response factor 10 \\
17 & Glyma.12G079300 & SAUR-like auxin-responsive protein family \\
\hline
\end{tabular}

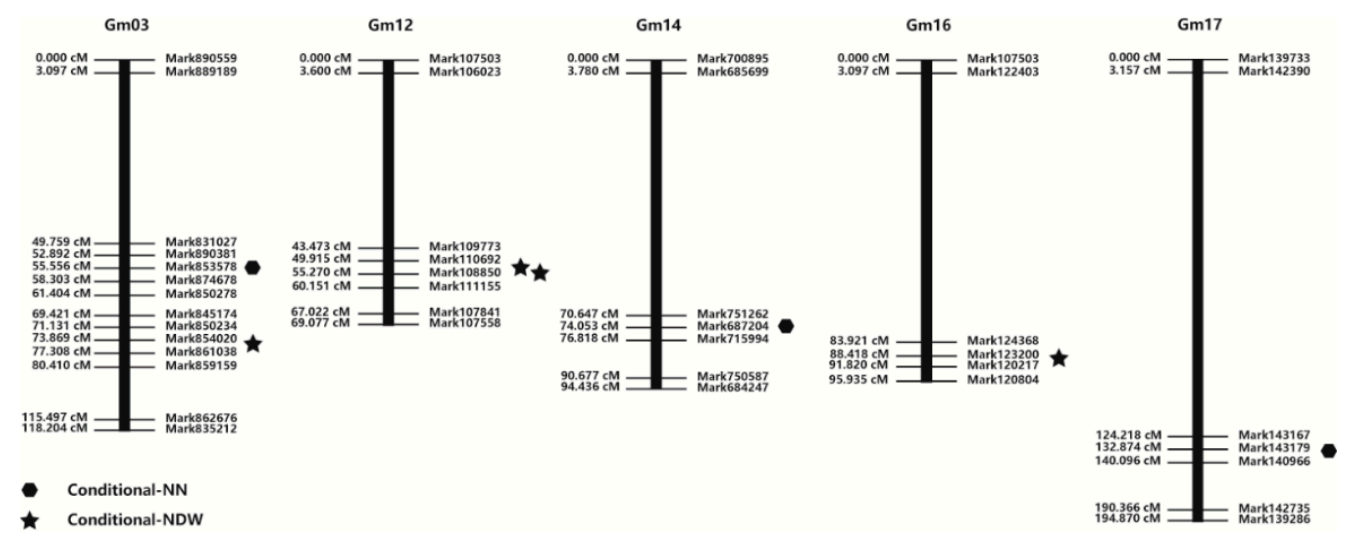

Figure 2. Chromosomal QTL locations of regions associated with the nodule traits of soybean. 


\subsection{Validation of Candidate Genes by $q R T-P C R$}

We analyzed the transcriptome of soybean germplasm Suinong14 inoculated with E. fredii HH103 or the rhcN mutant strain (data unpublished). The HH103 $r h c N$ gene encodes a protein that is $99.56 \%$ similar to the NGR234 rhcN protein, which is a T3SS protein that is similar to an ATPase believed to activate the secretion machinery and whose mutation eliminates T3SS secretion [60]. The $r h c N$ gene was disrupted with a kanamycin-resistance cassette to generate the $\mathrm{HH} 103 \Omega$ rhcN mutant. Subsequent inoculation experiments revealed that the wild-type HH103 and mutant $\mathrm{HH} 103 \Omega \mathrm{rhcN}$ E. fredii strains induced different expression patterns for seven genes (Glyma.12g028300, Glyma.12g030000, Glyma.12g036900, Glyma.12g052400, Glyma.12g055500, Glyma.12g031200, and Glyma.12g073000) (Figure 3 and Table 4). The transcriptome analysis suggested that these seven genes may affect T3SS signaling during rhizobial infections. These results implied that the expression of these genes was induced by rhizobia. However, the nodule phenotype differed between Sunong14 and Charleston. To determine whether these seven genes were associated with NopP, Charleston plants inoculated with E. fredii HH103 or HH103 $\Omega$ NopP were analyzed in a qRT-PCR assay, with non-inoculated plants as controls (Figure 4). Of these genes, only Glyma.12g031200 and Glyma.12g073000 were differentially expressed between Charleston plants inoculated with the wild-type or mutant E. fredii strains. Additionally, Glyma.12g031200 and Glyma.12g073000 were similarly expressed in Charleston plants regardless of the E. fredii strain. The peak Glyma.12g031200 and Glyma.12g073000 expression levels induced by the HH103 strain were detected at $36 \mathrm{~h}$ after inoculations, after which the expression levels decreased. In contrast, the HH103 $\Omega$ NopP strain had no effects on the expression patterns of these two genes. At $36 \mathrm{~h}$ after inoculations, the Glyma.12g031200 expression level was 2.3-times higher in plants inoculated with $\mathrm{HH} 103$ than in plants inoculated with HH103 $\Omega$ NopP, while the Glyma.12g073000 expression level was 5.4-times higher in plants inoculated

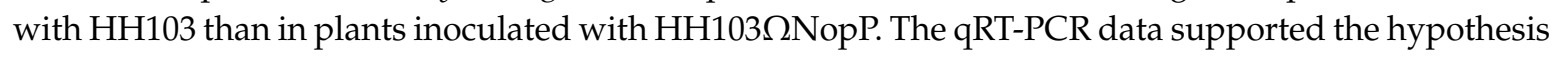
that Glyma.12g031200 and Glyma.12g073000 interact with NopP.

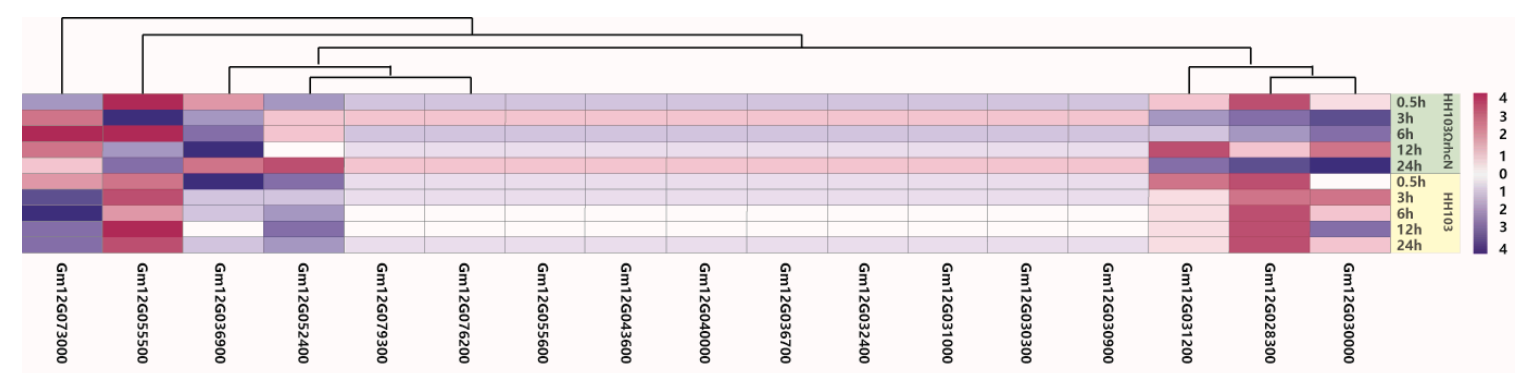

Figure 3. Heat map diagrams of relative expression levels of candidate genes inoculation with Ensifer fredii $\mathrm{HH} 103$ and Ensifer fredii $\mathrm{HH} 103 \Omega \mathrm{rhcN}, 0.5,3,6,12$, and $24 \mathrm{~h}$ post inoculation. Heatmap was plotted using heatmap. 2 function of the R/Bioconductor package gplots. Hierarchical clustering of the DEGs was done by complete method with Euclidean distance. The gene expression levels were transformed by $\log 2($ FPKM +1$)$ and the values were centered and scaled in row direction. $\mathrm{X}$-axis, differentially expressed gene names; Y-axis, samples. Purple and blue colors indicate a relative increase or decrease in expression inoculation with Ensifer fredii $\mathrm{HH} 103$ and Ensifer fredii $\mathrm{HH} 103 \Omega$ rhcN. Seven genes (Glyma.12g028300, Glyma.12g030000, Glyma.12g036900, Glyma.12g052400, Glyma.12g055500, Glyma.12g031200 and Glyma.12g073000) had different expression patterns inoculation with Ensifer fredii HH103 comparison with Ensifer fredii $\mathrm{HH} 103 \Omega$ rhcN mutant. 
Table 4. Annotation of candidate genes might interact with NopP.

\begin{tabular}{ccc}
\hline No. & Gene & Function \\
\hline 1 & Glyma.12G028300 & Cell elongation protein/DWARF1/Diminuto (DIM) \\
2 & Glyma.12G030000 & Leucine-rich repeat protein kinase family protein \\
3 & Glyma.12G031200 & Pathogenesis-related thaumatin superfamily protein \\
4 & Glyma.12G036900 & NAD(P)-binding rossmann-fold superfamily protein \\
5 & Glyma.12G052400 & Protein kinase family protein \\
6 & Glyma.12G055500 & Leucine-rich repeat (LRR) family protein \\
7 & Glyma.12G073000 & Mitogen-activated protein kinase 3 \\
\hline
\end{tabular}

Gene name and the functional annotation depending on the genomic information of soybean in phytotomy (https: / / phytozome.jgi.doe.gov/pz/portal.html\#!info?alias=Org_Gmax).

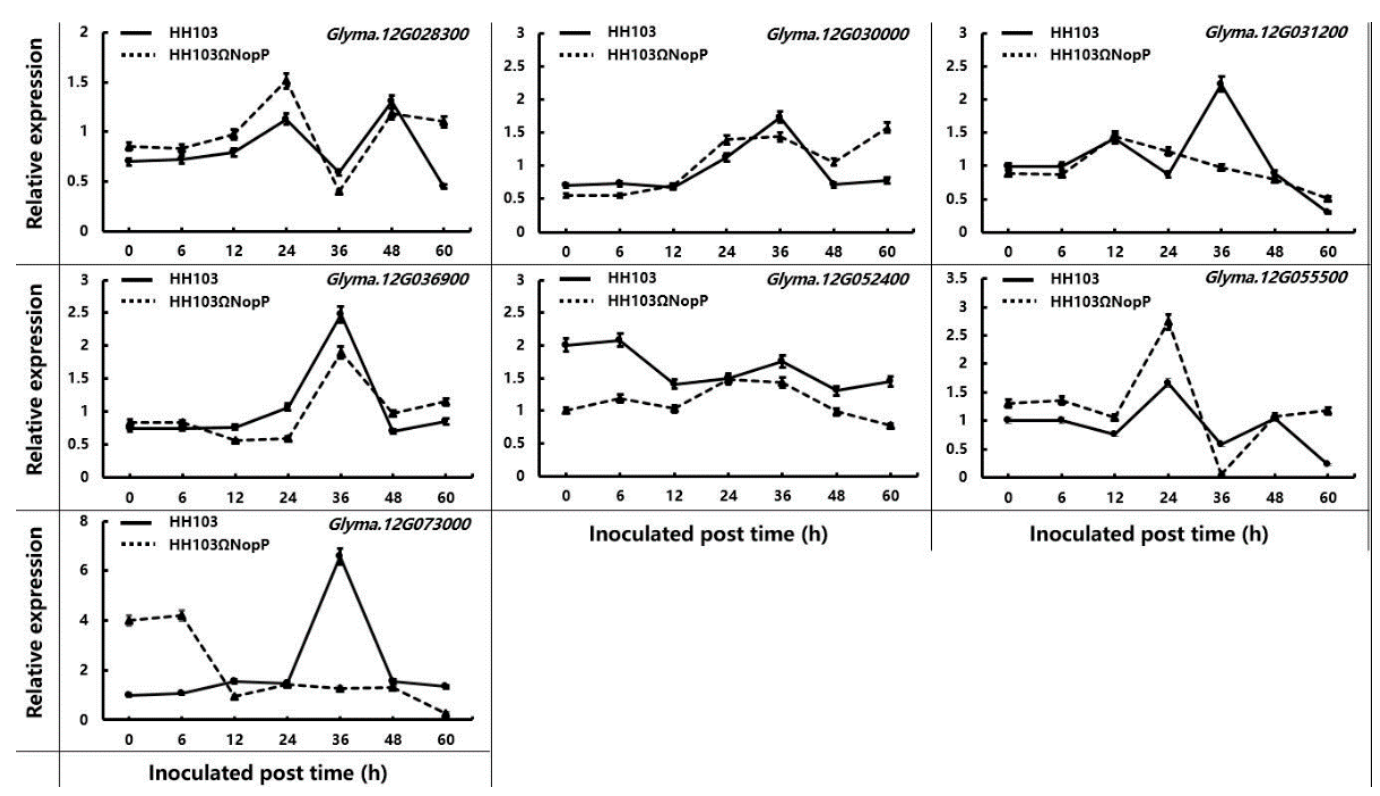

Figure 4. Relative expression levels of Glyma.12g028300, Glyma.12g030000, Glyma.12g031200, Glyma.12g036900, Glyma.12g052400, Glyma.12g055500 and Glyma.12g073000 in soybean roots after being

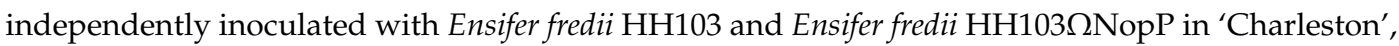
and non-inoculated plants as the control. The expression levels of target genes relative to the control samples at corresponding time points were calculated using the $2^{-\Delta \Delta C t}$ method. Bars represent the mean \pm SE (standard error) of three replications. Different letters represent significant differences $(p \leq 0.05)$ at each time point based on Duncan's multiple range test.

\section{Discussion}

Although several QTLs were detected in this study, it was difficult to determine which were associated with NopP. Nodule development in legumes (e.g., soybean) involves many processes. The detection of multiple QTLs may be indicative of the complexity in the signal exchange required between rhizobia and hosts to establish symbiosis. A previous study revealed that the correlation coefficients between BNF activity from acetylene reduction assays and NN and NDW were 0.44 and 0.70 , respectively [49]. The locus on $\mathrm{Gm} 03$ detected in the current study overlaps a previously identified QTL related to NDW [61]. Additionally, a locus related to NN on Gm16 [61] overlaps a locus adjacent to a QTL we detected. The conditional QTLs associated with NopP may be useful for identifying genes encoding proteins that interact with NopP. In this study, the detection of overlapping loci on Gm12 implies that the region encodes an interacting partner of NopP. Therefore, we analyzed the loci on Gm12 in greater detail.

The transcriptome analysis and qRT-PCR results indicated that the expression of two genes (Glyma.12g031200 and Glyma.12g073000) was interesting: They had a similar expression pattern after 
inoculation with the parental strain (maximum at $36 \mathrm{~h}$ post inoculation) that was not observed after

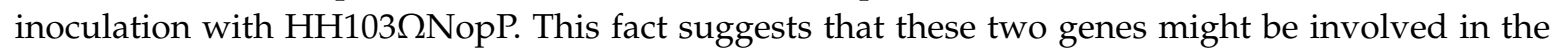
NopP-triggered signal pathway during nodule organogenesis. The Glyma.12g031200 encoded protein belongs to the pathogenesis-related 5 (PR5) family and shows amino acid sequence and protein structural similarities to the sweet tasting protein from Thaumatococcus daniellii [62], also named thaumatin-like proteins (TLPs). Many PR5 proteins have been identified in a wide range of plant species, such as wheat [63], soybean [57] and Avena sativa [64]. Some PR5 proteins have been proposed to participate in resistance to some pathogens, such as Arabidopsis thaliana ATLP3, that is induced by pathogenic fungi [65]. RlemTLP, a PR5 protein from rough lemon, has also been identified as a protein acting against pathogens [66]. Rj4, which codes for a thaumatin-like protein, participates in control nodulation specificity in soybean [57]. The action of Rj4 depends on the rhizobial type III secretion system (T3SS) [67]. The encoded product of Glyma.12g031200 belongs to the same TLP family that Rj4 and our transcriptome and qRT-PCR results support that NopP could induce Glyma.12g031200 expression. The fact that Glyma.12g031200 is not an R gene but encodes a thaumatin-like protein is kind of surprising. It will be interesting to understand how a thaumatin-like protein is involved in a NopP-triggered process in soybean-rhizobia interaction. However, more work is required to confirm the interaction pattern between NopP and Glyma.12g031200.

Glyma.12g073000 codes for a mitogen-activated protein kinase 3 (MAPK3), an important member of the MAPKs cascade. The mitogen-activated protein kinase (MAPK) genes are involved in various signalling pathways associated with biotic and abiotic stress responses in plants [68]. Previous studies have shown that various kinase activities are necessary in root nodule development in legumes [69,70]. TDY1, which encodes a MAPKs protein, has been identified to be involved in root nodulation and root tip development in Medicago [71]. In another legume, Lupinus albus, activation of MAPKs SIMK and SAMK is required for infection by bradyrhizobia [72]. Another study showed that a gene called GMK1, believed to encode a MAPK homolog, is involved in the symbiotic interaction between Bradyrhizobium japonicum USDA110 and soybean [73]. T3SS in bacteria also can mediate MAPKs when microbe infecting cells. For example, VopA, a T3SS effector of Vibrio parahaemolyticus could inhibit MAPKs pathway during host infection [74]. In this study, we show that the soybean MAPK3 encoding gene, Glyma.12g073000, is induced by HH103 when NopP is present, suggesting that this effector can induce a MAPK cascade in soybean roots. Further research is required to completely elucidate this issue.

The NopP type III effector is conserved in many rhizobial strains, but its effects on nodulation vary depending on the host plant species. For example, during infections of Pachyrhizus tuberosus, the E. fredii NGR234 mutant lacking a functional NopP cannot nodulate the host plant roots. In contrast, the inactivation of NopP increases the NN in the tropical legumes Flemingia congesta and Tephrosia vogelii [27]. Although NopP is produced by diverse rhizobia, there is no homology between the genes encoding NopP and Avr proteins from pathogens, suggesting that NopP is an effector that evolved in a legume-rhizobium symbiosis system. Moreover, depending on the NopP variant that interacts with Rj2, certain bradyrhizobial infections may be prevented via ETI [48]. Specifically, ETI is an accelerated and amplified pathogen-associated molecular pattern-triggered immunity response in which an $\mathrm{R}$ protein in the host plant directly or indirectly recognizes pathogen effectors, ultimately resulting in disease resistance $[75,76]$. The expression of many salicylic acid-dependent defense-signaling marker genes (e.g., $P R-1, P R-2$, and $P R-5$ ) may be induced after ETI is activated $[77,78]$. In soybean, GmPR1 expression may be upregulated following an infection by $E$. fredii HH103. Furthermore, $P R-2$ expression is reportedly significantly upregulated at 2 days after inoculation with $B$. diazoefficiens USDA122 relative to the expression levels in plants inoculated with the USDA122NopP 110 mutant and in uninoculated controls, but is markedly downregulated at 4 days after inoculation [48]. However, $P R-1$ and $P R-5$ expression levels are not significantly affected by B. diazoefficiens USDA122. The expression of Glyma.12g031200, which encodes a PR-5 protein, may be induced by NopP during the HH103 infection process. Thus, Glyma.12g031200 may be a new PR-5 protein that differs from those previously reported, and it may be involved in the induction of ETI resulting from interactions between NopP 
and Rj2. Like NopL, NopP can be phosphorylated by plant host kinases [30,38]. The phosphorylation of NopP may influence nodulation by inducing more signaling events. Therefore, the effects of HH103-secreted NopP on symbiotic relationships may be due to the complex interactions between effectors and the host plant. The MAPK-associated pathways have important roles in these complex interactions, and Glyma.12g073000 (MAPK3) may affect signal transduction pathways during NopP phosphorylation or the ETI-mediated by Rj2.

We propose that interactions between phosphorylated NopP and Rj2 in legumes induce signaling that upregulates TLP and MAPK3 expression to regulate nodule organogenesis. In this study, Glyma.12g031200 and Glyma.12g073000 were mapped using QTLs, and may be useful for detecting NopP signals involved in specific plant host signaling pathways. Identifying the genes encoding proteins that interact with specific type III effectors will increase our understanding of how symbiosis is established between rhizobia and soybean.

\section{Materials and Methods}

\subsection{Strains, Plasmids and Primers}

Ensifer fredii $\mathrm{HH} 103$ and its derived mutants, as well as Escherichia coli ' $\mathrm{DH} 5 \alpha^{\prime}$, were used in this study. Primers and plasmids are listed in Tables S1 and S2.

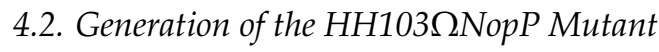

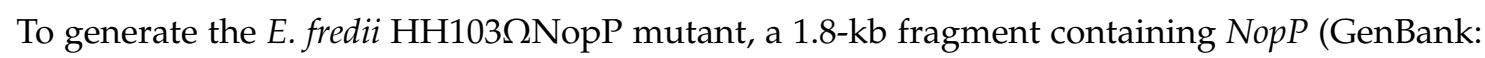
AAY33495.1) was cloned into pGWC to construct the pGWC-NopP1800 vector. A BamHI restriction enzyme site was introduced close to the ATG codon of NopP by PCR-based site-directed mutagenesis. An $\Omega$ interposon with the kanamycin resistance gene was excised from pEASY-T1 (Transgene Biotech Co., Beijing, China) by a PCR amplification with gene-specific primers with BamHI restriction enzyme sites (Table S1). The amplified fragment was purified, digested with BamHI, and ligated into the

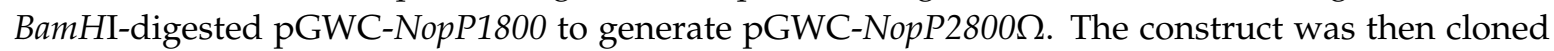

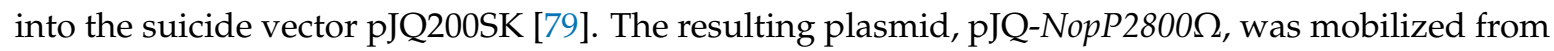
E. coli (DH5 $\alpha$ ) cells into E. fredii $\mathrm{HH} 103$ by triparental mating with the pRK2013 helper plasmid [80]. Putative transformants were detected based on kanamycin resistance and growth on $5 \%(w / v)$ sucrose.

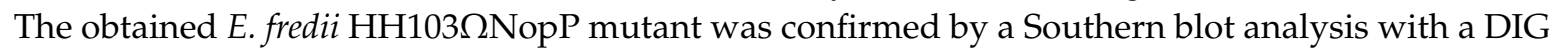
DNA-labeling and detection kit (Roche, Basel, Switzerland).

\subsection{Nodulation Tests}

Plant Materials and Nodulation-Related Traits

The germplasms used were Baimaodou, Qingdou, Huangpishanzibai, Wanhuangdadou, Heidou, Bayuezha, Suinong14, ZYD00006, Dongnong594 and Charleston, which are derived from different ecoregions. All of the seeds of the different populations and germplasms were surface sterilized and germinated on sterile plastic plates. Plantlets were transferred to 300-mL plastic jar (Magenta jar) units linked with a cotton wick (a mixture of vermiculite and expanded clay in the upper vessel; nitrogen-free nutrient solution in the lower vessel) under greenhouse conditions [7,30]. Five replicates and three independent experiments were performed. The soybean seeds were subjected to three major seed sterilization treatments, using chlorine gas, commercial Clorox bleach, containing $5.25 \%$ bleach, and $3 \%(v / v)$ hydrogen peroxide, and were then germinated on agar plates. Plants (one plant per jar) were inoculated with 109 bacteria (strain HH103 and mutant derivatives; see Table S2) at the Vc stage [61]. Plants were cultivated at $25 \pm 2{ }^{\circ} \mathrm{C}$ in a temperature-controlled greenhouse with a 16-h photoperiod. Four weeks after inoculation, plants were harvested for nodulation evaluation, as assessed by nodule number (NN) and nodule dry weight (NDW). $t$-tests were used to detect the statistical significances of phenotypes. 


\subsection{The Conditional QTL Mapping of Nodulation-Related Traits}

The experimental RIL population used in this study ('Charleston' $\times$ 'Dongnong594', $n=150$ ) originated from two individual lines, Charleston and Dongnong594 [81]. To map QTLs controlling nodule-related traits in the RIL population of 'Charleston' $\times$ 'Dongnong594', we used the method of composite interval mapping [61], with WinQTL Cartographer [61]. The control marker number and window size were five and $10 \mathrm{cM}$, respectively. A walk speed of $0.5 \mathrm{cM}$ and the forward regression method were selected. The proportion of the variance explained by each particular QTL and the additive effects were obtained from the composite interval mapping analysis. LOD score peaks greater than 2.0 (WinQTL Cartographer default threshold) indicated the existence of conditional QTLs for the two nodule traits after being independently inoculated with the two type strains studied here. For the additive-effects signals, ' + ' indicates increasing allelic effects from 'Dongnong594' and ' - ' indicates decreasing allelic effects from 'Charleston'. The experimental threshold levels for linkage were calculated from 1000 permutations of each genotypic marker against the phenotype in the population. Linkage was reported as significant if the two values for a marker were greater than the critical value at $p=0.05$ [82]. The NopP genes results in differences between the parental strains

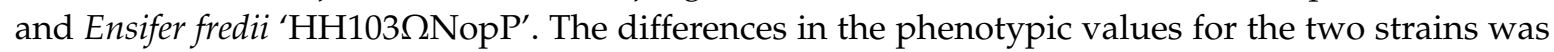
caused by NopP. The differences in phenotypic values were used to determine the conditional QTLs' locations [61].

\subsection{Delimitation of QTL Regions and Identification of Candidate Genes}

The identification of genes within the QTL regions was performed as described previously [1]. Briefly, each QTL was bound by two specific-length amplified fragment markers from a previously published high-quality genetic map [83]. A BLAST algorithm-based search of the soybean genome was performed (http:/ / soybase.org/gbrowse/cgi-bin/gbrowse/gmax1.01/), and gene names and descriptions were obtained (http://soybase.org/gbrowse/cgi-bin/gbrowse/gmax1.01/) [61]. The predicted coding DNA sequences for QTL regions in soybean were retrieved from the Phytozome website (www.phytozome.net/soybean) and were annotated by querying them against the G. max 'Wm82' proteome using BLASTX [82].

\subsection{RNA Isolation and qRT-PCR Analyses of NopP Candidate Genes}

To identify candidate genes that may interact with NopP, qRT-PCR was performed to measure the relative transcript levels of these genes in 'Charleston'. The total RNAs of the roots were isolated using an EasyPure ${ }^{\circledR}$ Plant RNA Kit (Transgene Biotech Co.), followed by an RNase-free gDNA wiper treatment (Vazyme Biotech Co., Nanjing, China), and then each RNA sample was converted into cDNA using the HiScript ${ }^{\circledR}$ II Q RT SuperMix (Vazyme Biotech Co.). Root samples were taken at 0, 12,

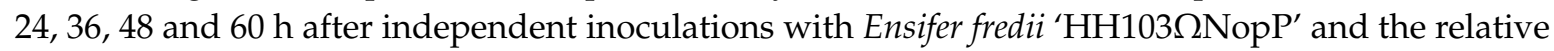
parental strain. They were ground to a fine powder in a liquid nitrogen-precooled mortar. qRT-PCR was performed with ChamQ ${ }^{\mathrm{TM}}$ Universal SYBR ${ }^{\circledR}$ qPCR Master Mix (Vazyme Biotech Co.) on a Roche LightCycler 480 II System (Roche). The qRT-PCR program was as follows: denaturation at $95^{\circ} \mathrm{C}$ for $2 \mathrm{~min}$, followed by 40 cycles of $95^{\circ} \mathrm{C}$ for $10 \mathrm{~s}, 60^{\circ} \mathrm{C}$ for $30 \mathrm{~s}$ and $72{ }^{\circ} \mathrm{C}$ for $30 \mathrm{~s}$. All RNA extractions were performed in three biological replicates, and each cDNA sample was analyzed three times. GmUNK1 (Glyma.12g020500) was used as the reference gene to calibrate the transcript abundance values among different samples [84]. The Ct values were calculated by the Roche LightCycler $480 \mathrm{II}$ software. The primer sequences of the qRT-PCR target genes are listed in Table S1.

Supplementary Materials: The following are available online at http:/ / www.mdpi.com/1422-0067/19/11/3438/ s1, Table S1, Information of Primers Used; Table S2. Information of Strains and Vectors. 
Author Contributions: D.X., Q.C. and X.W. conceived the study, and designed and managed the experiments. H.J., Z.Q., Z.H., Jie.W., Y.Z., Q.L., Q.Z. and J.Z. provided plant lines. Jin.W., Jie.W.,Chu.L. Cha.L., C.M., Y.W., Z.S. and H.L. performed trials and collected data. Z.Y., Y.S., J.Z., R.Z. and Jin.W. completed statistical analyses of phenotypic data and wrote the paper. D.X., Q.C., Jin.W., X.W., Z.Q. and Z.H. all contributed to writing the paper.

Funding: Financial support was received from the Ministry of Science and Technology of People's Republic of China Project (Grant number: 2017YFE0111000), the National Natural Science Foundation of China (Grant numbers: 31400074, 31471516, 31271747 and 30971809), the Natural Science Foundation of Heilongjiang Province of China (Grant number: ZD201213), the Heilongjiang Postdoctoral Science Foundation (Grant number: LBH-Q16014), Harbin Science Technology Project (Grant numbers: 2013RFQXJ005 and 2014RFXXJ012), and the National Key R\&D Program of China (Grant numbers: 2016YFD0100500, 2016YFD0100300 and 2016YFD0100201-21). Foundation for University Key Teachers from the education department of Heilongjiang Province in China (1254G011).

Acknowledgments: We thank Lesley Benyon, from Liwen Bianji, Edanz Group China (www.liwenbianji.cn/ac), for editing the English text of a draft of this manuscript.

Conflicts of Interest: The authors declare that they have no conflict of interest.

\section{References}

1. Xin, D.W.; Qi, Z.M.; Jiang, H.W.; Hu, Z.B.; Zhu, R.S.; Hu, J.H.; Han, H.Y.; Hu, G.H.; Liu, C.Y.; Chen, Q.S. QTL Location and Epistatic Effect Analysis of 100-Seed Weight Using Wild Soybean (Glycine soja Sieb. \& Zucc.) Chromosome Segment Substitution Lines. PLoS ONE 2016, 11, e0149380. [CrossRef]

2. Zimmer, S.; Messmer, M.; Haase, T.; Piepho, H.P.; Mindermann, A.; Schulz, H.; Habekuß, A.; Ordon, F.; Wilbois, P.H.; Heß, J. Effects of soybean variety and Bradyrhizobium strains on yield, protein content and biological nitrogen fixation under cool growing conditions in Germany. Eur. J. Agron. 2016, 72, 38-46. [CrossRef]

3. Riely, B.K.; Larrainzar, E.; Haney, C.H.; Mun, J.H.; Gil-Quintana, E.; González, E.M.; Yu, H.J.; Tricoli, D.; Ehrhardt, D.W.; Cook, D.R. Development of tools for the biochemical characterization of the symbiotic receptor-like kinase DMI2. Mol. Plant Microbe Interact. 2013, 26, 216-226. [CrossRef] [PubMed]

4. Riches, D.; Porter, I.J.; Oliver, D.P.; Bramley, R.G.V.; Rawnsley, B.; Edwards, J.; White, R.E. Soil biological properties as indicators of soil quality in A ustralian viticulture. Aust. J. Grape Wine Res. 2003, 19, 311-323. [CrossRef]

5. Buendía-Clavería, A.M.; Moussaid, A.; Ollero, F.J.; Vinardell, J.M.; Torres, A.; Moreno, J.; Gil-Serrano, A.M.; Rodríguez-Carvajal, M.A.; Tejero-Mateo, P.; Peart, J.L. A purL mutant of Sinorhizobium fredii HH103 is symbiotically defective and altered in its lipopolysaccharide. Microbiology 2003, 149, 1807-1818. [CrossRef] [PubMed]

6. Chen, W.X.; Yan, G.H.; Li, J.L. Numerical taxonomy study of fast-growing soybean rhizobia and a proposal that Rhizobium fredii be assigned to Sinorhizobium gen. nov. Int. J. Syst. Evol. Microbiol. 1988, 38, 392-397. [CrossRef]

7. Pueppke, S.G.; Broughton, W.J. Rhizobium sp. strain NGR234 and R. fredii USDA257 share exceptionally broad, nested host ranges. Mol. Plant Microbe Interact. 1999, 12, 293-318. [CrossRef] [PubMed]

8. López-Baena, F.J.; Ruiz-Sainz, J.E.; Rodríguez-Carvajal, M.A.; Vinardell, J.M. Bacterial Molecular Signals in the Sinorhizobium fredii-Soybean Symbiosis. Int. J. Mol. Sci. 2016, 17, 755. [CrossRef] [PubMed]

9. Jiménez-Guerrero, I.; Pérez-Montaño, F.; Medina, C.; Ollero, F.J.; López-Baena, F.J. The Sinorhizobium (Ensifer) fredii HH103 nodulation outer protein NopI is a determinant for efficient nodulation of soybean and cowpea plants. Appl. Environ. Microbiol. 2016, 83, e02770-16. [CrossRef] [PubMed]

10. Margaret, I.; Becker, A.; Blom, J.; Bonilla, I.; Goesmann, A.; Göttfert, M.; Lloret, J.; Mittard-Runte, V.; Rückert, C.; Ruiz-Sainz, J.E.; et al. Symbiotic properties and first analyses of the genomic sequence of the fast growing model strain Sinorhizobium fredii HH103 nodulating soybean. J. Biotechnol. 2011, 155, 11-19. [CrossRef] [PubMed]

11. Weidner, S.; Becker, A.; Bonilla, I.; Jaenicke, S.; Lloret, J.; Margaret, I.; Pühler, A.; Ruiz-Sainz, J.E.; Schneiker-Bekel, S.; Szczepanowski, R.; et al. Genome sequence of the soybean symbiont Sinorhizobium fredii HH103. J. Biotechnol. 2012, 194, 1617-1618. [CrossRef] [PubMed]

12. Vinardell, J.M.; Acostajurado, S.; Zehner, S.; Göttfert, M.; Becker, A.; Baena, I.; Blom, J.; Goesmann, A.; Jaenicke, S.; Krol, E.; et al. The Sinorhizobium fredii HH103 genome: A comparative analysis with S. fredii 
strains differing in their symbiotic behavior with soybean. Mol. Plant Microbe Interact. 2015, 28, 811-824. [CrossRef] [PubMed]

13. Pérez-Montaño, F.; Jiménez-Guerrero, I.; Acosta-Jurado, S.; Navarro-Gómez, P.; Ollero, F.J.; Ruiz-Sainz, J.E.; López-Baena, F.J.; Vinardell, J.M. A transcriptomic analysis of the effect of genistein on Sinorhizobium fredii HH103 reveals novel rhizobial genes putatively involved in symbiosis. Sci. Rep. 2016, 19, 31592. [CrossRef] [PubMed]

14. Miwa, H.; Okazaki, S. How effectors promote beneficial interactions. Curr. Opin. Plant Biol. 2017, 38, $148-154$. [CrossRef] [PubMed]

15. Cai, J.; Zhang, L.Y.; Liu, W.; Tian, Y.; Xiong, J.S.; Wang, Y.H.; Li, R.J.; Li, H.M.; Wen, J.Q.; Mysore, K.S.; et al. Role of the Nod factor hydrolase MtNFH1 in regulating Nod factor levels during rhizobial infection and in mature nodules of Medicago truncatula. Plant Cell 2018. [CrossRef] [PubMed]

16. Gourion, B.; Berrabah, F.; Ratet, P.; Stacey, G. Rhizobium-legume symbioses: The crucial role of plant immunity. Trends Plant Sci. 2015, 20, 186-194. [CrossRef] [PubMed]

17. Gully, D.; Gargani, D.; Bonaldi, K.; Grangeteau, C.; Chaintreuil, C.; Fardoux, J.; Nguyen, P.; Marchetti, R.; Nouwen, N.; Molinaro, A. A peptidoglycan-remodeling enzyme is critical for bacteroid differentiation in Bradyrhizobium spp. during legume symbiosis. Mol. Plant Microbe Interact. 2016, 29, 447-457. [CrossRef] [PubMed]

18. Wang, D.; Yang, S.; Tang, F.; Zhu, H. Symbiosis specificity in the legume-rhizobial mutualism. Cell Microbiol. 2012, 14, 334-342. [CrossRef] [PubMed]

19. Kawaharada, Y.; Kelly, S.; Nielsen, M.W.; Hjuler, C.T.; Gysel, K.; Muszyński, A.; Carlson, R.W.; Thygesen, M.B.; Snadal, N.; Asmussen, M.H. Receptor-mediated exopolysaccharide perception controls bacterial infection. Nature 2015, 523, 308. [CrossRef] [PubMed]

20. Cao, Y.; Halane, M.K.; Gassmann, W.; Stacey, G. The role of plant innate immunity in the legume-rhizobium symbiosis. Ann. Rev. Plant Biol. 2017, 68, 535-561. [CrossRef] [PubMed]

21. Remigi, P.; Zhu, J.; Young, J.P.W.; Masson-Boivin, C. Symbiosis within symbiosis: Evolving nitrogen-fixing legume symbionts. Trends Microbiol. 2016, 24, 63-75. [CrossRef] [PubMed]

22. Marie, C.; Deakin, W.J.; Viprey, V.; Kopciñska, J.; Golinowski, W.; Krishnan, H.B.; Perret, X.; Broughton, W.J. Characterization of Nops, nodulation outer proteins, secreted via the type III secretion system of NGR234. Mol. Plant Microbe Interact. 2003, 16, 743-751. [CrossRef] [PubMed]

23. Tampakaki, A.P. Commonalities and differences of T3SSs in rhizobia and plant pathogenic bacteria. Front Plant Sci. 2014, 5, 114. [CrossRef] [PubMed]

24. Staehelin, C.; Krishnan, H.B. Nodulation outer proteins: Double-edged swords of symbiotic rhizobia. Biochem. J. 2015, 470, 263-274. [CrossRef] [PubMed]

25. Krishnan, H.B. NolX of Sinorhizobium fredii USDA257, a type III-secreted protein involved in host range determination, is localized in the infection threads of cowpea (Vigna unguiculata [L.] Walp) and soybean (Glycine max [L.] Merr.) nodules. J. Bacteriol. 2002, 184, 831-839. [CrossRef] [PubMed]

26. Bartsev, A.V.; Boukli, N.M.; Deakin, W.J.; Staehelin, C.; Broughton, W.J. Purification and phosphorylation of the effector protein NopL from Rhizobium sp. NGR234. FEBS Lett. 2003, 554, 271-274. [CrossRef]

27. Ausmees, N.; Kobayashi, H.; Deakin, W.J.; Marie, C.; Krishnan, H.B.; Broughton, W.J.; Perret, X. Characterization of NopP, a type III secreted effector of Rhizobium sp. strain NGR234. J. Bacteriol. 2004, 186, 4774-4780. [CrossRef] [PubMed]

28. Lorio, J.C.; Kim, W.S.; Krishnan, H.B. NopB, a soybean cultivar-specificity protein from Sinorhizobium fredii USDA257, is a type III secreted protein. Mol. Plant Microbe Interact. 2004, 17, 1259-1268. [CrossRef] [PubMed]

29. Deakin, W.J.; Marie, C.; Saad, M.M.; Krishnan, H.B.; Broughton, W.J. NopA is associated with cell surface appendages produced by the type III secretion system of Rhizobium sp. strain NGR234. Mol. Plant Microbe Interact. 2005, 18, 499-507. [CrossRef] [PubMed]

30. Skorpil, P.; Saad, M.M.; Boukli, N.M.; Kobayashi, H.; Ares-Orpel, F.; Broughton, W.J.; Deakin, W.J. NopP, a phosphorylated effector of Rhizobium sp. strain NGR234, is a major determinant of nodulation of the tropical legumes Flemingia congesta and Tephrosia vogelii. Mol. Microbiol. 2005, 57, 1304-1317. [CrossRef] [PubMed] 
31. Rodrigues, J.A.; Lopez-Baena, F.J.; Ollero, F.J.; Vinardell, J.M.; Espuny, M.D.; Bellogín, R.A.; Thomas, J.R.; Sumpton, D.; Ault, J.; Thomas-Oates, J. NopM and NopD are rhizobial nodulation outer proteins: Identification using LC-MALDI and LC-ESI with a monolithic capillary column. J. Proteome Res. 2007, 6, 1029-1037. [CrossRef] [PubMed]

32. Dai, W.J.; Zeng, Y.; Xie, Z.P.; Staehelin, C. Symbiosis-promoting and deleterious effects of NopT, a novel type 3 effector of Rhizobium sp. strain NGR234. J. Bacteriol. 2008, 190, 5101-5110. [CrossRef] [PubMed]

33. Saad, M.M.; Staehelin, C.; Broughton, W.J.; Deakin, W.J. Protein-protein interactions within type III secretion system-dependent pili of Rhizobium sp. strain NGR234. J. Bacteriol. 2008, 190, 750-754. [CrossRef] [PubMed]

34. Kambara, K.; Ardissone, S.; Kobayashi, H.; Saad, M.M.; Schumpp, O.; Broughton, W.J.; Deakin, W.J. Rhizobia utilize pathogen-like effector proteins during symbiosis. Mol. Microbiol. 2009, 71, 92-106. [CrossRef] [PubMed]

35. Zhang, L.; Chen, X.J.; Lu, H.B.; Xie, Z.P.; Staehelin, C. Functional analysis of the type 3 effector NopL from Rhizobium sp. NGR234: Symbiotic effects, phosphorylation and interference with MAPK signaling. J. Biol. Chem. 2011, jbc-M111, 265942. [CrossRef]

36. Xin, D.W.; Liao, S.; Xie, Z.P.; Hann, D.R.; Steinle, L.; Boller, T.; Staehelin, C. Functional analysis of NopM, a novel E3 ubiquitin ligase (NEL) domain effector of Rhizobium sp. strain NGR234. PLoS Pathog. 2012, 8, e1002707. [CrossRef] [PubMed]

37. Kimbrel, J.A.; Thomas, W.J.; Jiang, Y.; Creason, A.L.; Thireault, C.A.; Sachs, J.L.; Chang, J.H. Mutualistic co-evolution of type III effector genes in Sinorhizobium fredii and Bradyrhizobium japonicum. PLoS Pathog. 2013, 9, e1003204. [CrossRef] [PubMed]

38. Ge, Y.Y.; Xiang, Q.W.; Wagner, C.; Zhang, D.; Xie, Z.P.; Staehelin, C. The type 3 effector NopL of Sinorhizobium sp. strain NGR234 is a mitogen-activated protein kinase substrate. J. Exp. Bot. 2016, 67, 2483-2494. [CrossRef] [PubMed]

39. Jiménez-Guerrero, I.; Pérez-Montaño, F.; Medina, C.; Ollero, F.J.; López-Baena, F.J. NopC is a Rhizobium-specific type 3 secretion system effector secreted by Sinorhizobium (Ensifer) fredii HH103. PLoS ONE 2015, 10, e0142866. [CrossRef] [PubMed]

40. Schechter, L.M.; Guenther, J.; Olcay, E.A.; Jang, S.; Krishnan, H.B. Translocation of NopP by Sinorhizobium fredii USDA257 into Vigna unguiculata root nodules. Appl. Environ. Microbiol. 2010, 76, 3758-3761. [CrossRef] [PubMed]

41. López-Baena, F.J.; Monreal, J.A.; Pérez-Montaño, F.; Guasch-Vidal, B.; Bellogín, R.A.; Vinardell, J.M.; Ollero, F.J. The absence of Nops secretion in Sinorhizobium fredii HH103 increases GmPR1 expression in Williams soybean. Mol. Plant Microbe Interact. 2009, 22, 1445-1454. [CrossRef] [PubMed]

42. Hajimorad, M.R.; Hill, J.H. Rsv1-mediated resistance against Soybean mosaic virus-N is hypersensitive response-independent at inoculation site, but has the potential to initiate a hypersensitive response-like mechanism. Mol. Plant Microbe Interact. 2001, 14, 587-598. [CrossRef] [PubMed]

43. Thomma, B.P.; Penninckx, I.A.; Cammue, B.P.; Broekaert, W.F. The complexity of disease signaling in Arabidopsis. Curr. Opin. Immunol. 2001, 13, 63-68. [CrossRef]

44. Jones, D.A.; Takemoto, D. Plant innate immunity-direct and indirect recognition of general and specific pathogen-associated molecules. Curr. Opin. Immunol. 2004, 16, 48-62. [CrossRef] [PubMed]

45. Hayashi, M.; Saeki, Y.; Haga, M.; Harada, K.; Kouchi, H.; Umehara, Y. Rj (rj) genes involved in nitrogen-fixing root nodule formation in soybean. Breeding Sci. 2012, 61, 544-553. [CrossRef] [PubMed]

46. Caldwell, B.E.; Vest, G. Nodulation interactions between soybean genotypes and serogroups of Rhizobium japonicum. Crop Sci. 1968, 8, 680-682. [CrossRef]

47. Tsukui, T.; Eda, S.; Kaneko, T.; Sato, S.; Okazaki, S.; Kakizaki-Chiba, K.; Itakura, M.; Mitsui, H.; Yamashita, A.; Terasawa, K.; et al. The type III secretion system of Bradyrhizobium japonicum USDA122 mediates symbiotic incompatibility with Rj2 soybean plants. Appl. Environ. Microbiol. 2013, 79, 1048-1051. [CrossRef] [PubMed]

48. Sugawara, M.; Takahashi, S.; Umehara, Y.; Iwano, H.; Tsurumaru, H.; Odake, H.; Suzuki, Y.; Kondo, H.; Konno, Y.; Yamakawa, T.; et al. Variation in bradyrhizobial NopP effector determines symbiotic incompatibility with Rj2-soybeans via effector-triggered immunity. Nat. Commun. 2018, 9, 3139. [CrossRef] [PubMed]

49. Hwang, S.; Ray, J.D.; Cregan, P.B.; King, C.A.; Davies, M.K.; Purcell, L.C. Genetics and mapping of quantitative traits for nodule number, weight, and size in soybean (Glycine max L.[Merr.]). Euphytica 2014, 195, 419-434. [CrossRef] 
50. Santos, M.A.; Geraldi, I.O.; Garcia, A.A.F.; Bortolatto, N.; Schiavon, A.; Hungria, M. Mapping of QTLs associated with biological nitrogen fixation traits in soybean. Hereditas 2013, 150, 17-25. [CrossRef] [PubMed]

51. Caetano-Anolles, G.; Gresshoff, P.M. Plant genetic control of nodulation. Ann. Rev. Microbiol. 1991, 45, 345-382. [CrossRef] [PubMed]

52. Caldwell, B.E. Inheritance of a Strain-Specific Ineffective Nodulation in Soybeans. Crop Sci. 1966, 6, 427-428. [CrossRef]

53. Vest, G. Rj3 A Gene Conditioning Ineffective Nodulation in Soybean. Crop Sci. 1970, 10, 34-35. [CrossRef]

54. Vest, G.; Caldwell, B.E. Rj4-A Gene Conditioning Ineffective Nodulation in Soybean. Crop Sci. 1972, 12, 692-693. [CrossRef]

55. Vuong, T.D.; Nickell, C.D.; Harper, J.E. Genetic and allelism analyses of hypernodulation soybean mutants from two genetic backgrounds. Crop Sci. 1996, 36, 1153-1158. [CrossRef]

56. Yang, S.M.; Tang, F.; Gao, M.Q.; Krishnan, H.B.; Zhu, H.Y. R gene-controlled host specificity in the legume-rhizobia symbiosis. Proc. Natl. Acad. Sci. USA 2010, 201011957. [CrossRef] [PubMed]

57. Tang, F.; Yang, S.M.; Liu, J.G.; Zhu, H.Y. Rj4, a gene controlling nodulation specificity in soybeans, encodes a thaumatin-like protein but not the one previously reported. Plant Physiol. 2016, 170, 26-32. [CrossRef] [PubMed]

58. Okazaki, S.; Kaneko, T.; Sato, S.; Saeki, K. Hijacking of leguminous nodulation signaling by the rhizobial type III secretion system. Proc. Natl. Acad. Sci. USA 2013, 201302360. [CrossRef] [PubMed]

59. Faruque, O.M.; Miwa, H.; Yasuda, M.; Fujii, Y.; Kaneko, T.; Sato, S.; Okazaki, S. Identification of Bradyrhizobium elkanii genes involved in incompatibility with soybean plants carrying the Rj4 allele. Appl. Environ. Microbiol. 2015, 81, 6710-6717. [CrossRef] [PubMed]

60. Viprey, V.; Del Greco, A.; Golinowski, W.; Broughton, W.J.; Perret, X. Symbiotic implications of type III protein secretion machinery in Rhizobium. Mol. Microbiol. 1998, 28, 1381-1389. [CrossRef] [PubMed]

61. Zhang, Y.J.; Liu, X.Y.; Chen, L.; Fu, Y.; Li, C.Y.; Qi, Z.M.; Zou, J.N.; Zhu, R.S.; Li, S.P.; Wei, W.; et al. Mining for genes encoding proteins associated with NopL of Sinorhizobium fredii HH103 using quantitative trait loci in soybean (Glycine max Merr.) recombinant inbred lines. Plant Soil 2018, 431, 245-255. [CrossRef]

62. Edens, L.; Heslinga, L.; Klok, R.; Ledeboer, M.A.; Maat, J.; Toonen, M.Y.; Visser, C.; Theo Verrips, C. Cloning of cDNA encoding the sweet-tasting plant protein thaumatin and its expression in Escherichia coli. Gene 1982, 18, 1-12. [CrossRef]

63. Wang, X.J.; Tang, C.L.; Deng, L.; Cai, G.L.; Liu, X.Y.; Liu, B.; Han, Q.M.; Buchenauer, H.; Wei, G.R.; Han, D.Y.; et al. Characterization of a pathogenesis-related thaumatin-like protein gene TaPR5 from wheat induced by stripe rust fungus. Physiol. Plant. 2010, 139, 27-38. [CrossRef] [PubMed]

64. Lin, K.C.; Bushnell, W.R.; Szabo, L.J.; Smith, A.G. Isolation and expression of a host response gene family encoding thaumatin-like proteins in incompatible oat-stem rust fungus interactions. Mol. Plant Microbe Interact. 1996, 9, 511-522. [CrossRef] [PubMed]

65. Hu, X.; Reddy, A.S.N. Cloning and expression of a PR5-like protein from Arabidopsis: Inhibition of fungal growth by bacterially expressed protein. Plant Mol. Biol. 1997, 34, 949-959. [CrossRef] [PubMed]

66. Kim, B.G.; Fukumoto, T.; Tatano, S.; Gomi, K.; Ohtani, K.; Tada, Y.; Akimitsu, K. Molecular cloning and characterization of a thaumatin-like protein-encoding cDNA from rough lemon. Physiol. Mol. Plant Pathol. 2009, 74, 3-10. [CrossRef]

67. Okazaki, S.; Zehner, S.; Hempel, J.; Lang, K.; Göttfert, K. Genetic organization and functional analysis of the type III secretion system of Bradyrhizobium elkanii. FEMS Microbiol. Lett. 2009, 295, 88-95. [CrossRef] [PubMed]

68. Neupane, A.; Nepal, M.P.; Benson, B.V.; MacArthur, K.J.; Piya, S. Evolutionary history of mitogen-activated protein kinase (MAPK) genes in Lotus, Medicago, and Phaseolus. Plant Signal. Behav. 2013, 8, e27189. [CrossRef] [PubMed]

69. Grimsrud, P.A.; den Os, D.; Wenger, C.D.; Swaney, D.L.; Schwartz, D.; Sussman, M.R.; Ané, J.M.; Coon, J.J. Large-scale phosphoprotein analysis in Medicago truncatula roots provides insight into in vivo kinase activity in legumes. Plant Physiol. 2010, 152, 19-28. [CrossRef] [PubMed]

70. Khan, G.A.; Declerck, M.; Sorin, C.; Hartmann, C.; Crespi, M.; Lelandais-Brière, C. MicroRNAs as regulators of root development and architecture. Plant Mol. Biol. 2011, 77, 47-58. [CrossRef] [PubMed] 
71. Schoenbeck, M.A.; Samac, D.A.; Fedorova, M.; Gregerson, R.G.; Gantt, J.S.; Vance, C.P. The alfalfa (Medicago sativa) TDY1 gene encodes a mitogen-activated protein kinase homolog. Mol. Plant Microbe Interact. 1999, 12, 882-893. [CrossRef] [PubMed]

72. Fernandez-Pascual, M.; Lucas, M.M.; de Felipe, M.R.; Boscá, L.; Hirt, H.; Golvano, M.P. Involvement of mitogen-activated protein kinases in the symbiosis Bradyrhizobium-Lupinus. J. Exp. Bot. 2006, 57, 2735-2742. [CrossRef] [PubMed]

73. Lee, H.; Kim, J.; Im, J.H.; Kim, H.B.; Oh, C.J.; An, C.S. Mitogen-activated protein kinase is involved in the symbiotic interaction between Bradyrhizobium japonicum USDA110 and soybean. J. Plant Biol. 2008, 51, 291-296. [CrossRef]

74. Trosky, J.E.; Mukherjee, S.; Burdette, D.L.; Roberts, M.; McCarter, L.; Siegel, R.M.; Orth, K. Inhibition of MAPK signaling pathways by VopA from Vibrio parahaemolyticus. J. Biol. Chem. 2004, 279, 51953-51957. [CrossRef] [PubMed]

75. Jones, J.D.G.; Dangl, J.L. The plant immune system. Nature 2006, 444, 323. [CrossRef] [PubMed]

76. Cui, H.; Tsuda, K.; Parker, J.E. Effector-triggered immunity: From pathogen perception to robust defense. Ann. Rev. Plant Biol. 2015, 66, 487-511. [CrossRef] [PubMed]

77. Yoshioka, K.; Kachroo, P.; Tsui, F.; Sharma, S.B.; Shah, J.; Klessig, D.F. Environmentally sensitive, SA-dependent defense responses in the cpr22 mutant of Arabidopsis. Plant J. 2001, 26, 447-459. [CrossRef] [PubMed]

78. Yasuda, M.; Miwa, H.; Masuda, S.; Takebayashi, Y.; Sakakibara, H.; Okazaki, S. Effector-triggered immunity determines host genotype-specific incompatibility in legume-Rhizobium symbiosis. Plant Cell Physiol. 2016, 57, 1791-1800. [CrossRef] [PubMed]

79. Quandt, J.; Hynes, M.F. Versatile suicide vectors which allow direct selection for gene replacement in gram-negative bacteria. Gene 1993, 127, 15-21. [CrossRef]

80. Figurski, D.; Meyer, R.J.; Helinski, D.R. Suppression of ColE1 replication properties by the Inc P-1 plasmid RK2 in hybrid plasmids constructed in vitro. J. Mol. Biol. 1979, 133, 295-318. [CrossRef]

81. Jiang, H.W.; Li, Y.Y.; Qin, H.T.; Li, Y.L.; Qi, H.D.; Li, C.D.; Wang, N.N.; Li, R.C.; Zhao, Y.Y.; Huang, S.Y. Identification of Major QTLs Associated With First Pod Height and Candidate Gene Mining in Soybean. Front Plant Sci. 2018, 9. [CrossRef] [PubMed]

82. Brensha, W.; Kantartzi, S.K.; Meksem, K.; Grier IV, R.L.; Barakat, A.; Lightfoot, D.A.; Kassem, M.A. Genetic analysis of root and shoot traits in the 'Essex' by 'Forrest' recombinant inbred line (RIL) population of soybean [Glycine max (L.) Merr.]. Plant Genet. Genom. Biotechnol. 2012, 1, 1-9. [CrossRef]

83. Qi, Z.M.; Huang, L.; Zhu, R.S.; Xin, D.W.; Liu, C.Y.; Han, X.; Jiang, H.W.; Chen, Q.S. A high-density genetic map for soybean based on specific length amplified fragment sequencing. PLoS ONE 2014, 9, e104871. [CrossRef] [PubMed]

84. Hu, R.; Fan, C.; Li, H.; Zhang, Q.; Fu, Y.F. Evaluation of putative reference genes for gene expression normalization in soybean by quantitative real-time RT-PCR. BMC Mol. Biol. 2009, 10, 93. [CrossRef] [PubMed]

(C) 2018 by the authors. Licensee MDPI, Basel, Switzerland. This article is an open access article distributed under the terms and conditions of the Creative Commons Attribution (CC BY) license (http:// creativecommons.org/licenses/by/4.0/). 